\title{
板状デバイスの非線形マルチスケール解析に 対する数値平板試験
}

佐藤 維美 1 - 村松 眞由 2 - 松原 成志朗 3 - 西 紳之介 4 - 寺田 賢二郎 5 八代 圭司 $6 \cdot$ ・田 達也 7

\author{
1 東北大学 災害科学国際研究所（干980-0845 宮城県仙台市青葉区荒巻字 468-1） \\ E-mail:satom@irides.tohoku.ac.jp \\ 2 東北大学大学院 環境科学研究科（干980-0845 宮城県仙台市青葉区荒巻字 468-1） \\ E-mail: muramatsu@ee.mech.tohoku.ac.jp \\ 3 東北大学大学院 工学研究科 土木工学専攻（干980-0845 宮城県仙台市青葉区荒巻字 468-1) \\ E-mail: seishiro.matsubara.t4@dc.tohoku.ac.jp \\ 4 東北大学大学院 工学研究科 土木工学専攻（干980-0845 宮城県仙台市青葉区荒巻字 468-1） \\ E-mail: shinnosuke.nishi.p5@dc.tohoku.ac.jp \\ 5 正会員 東北大学教授 災害科学国際研究所（干980-0845 宮城県仙台市青葉区荒巻字 468-1） \\ E-mail: tei@irides.tohoku.ac.jp \\ 6 東北大学准教授 環境科学研究科（干980-8579 宮城県仙台市青葉区荒巻字青葉 6-6-01） \\ E-mail: yashiro@ee.mech.tohoku.ac.jp \\ 7 東北大学教授＼cjkstart環境科学研究科（ \\ E-mail:kawada@ee.mech.tohoku.ac.jp
}

\begin{abstract}
本論文では, 単一セルが面内に周期的な構造を有する複合板とみなせるような固体酸化物形燃料電池 (Solid Oxide Fuel Cell : SOFC) を対象として, そのミクロ-マクロ連成解析の多段階解析を実現するため に, 汎用 FEM ソフトウェアを用いて面内周期的な単一ミクロ構造（面内ユニット構造）に対する数值平 板試験を実施する。そして，均質な板としてのマクロ非線形力学挙動を特徵づけたうえで，これと等価な マクロ挙動を表現する面内ユニット構造の代理モデルとして積層板の均質なミクロ構造を設定し, 各層の 材料特性を同定することで汎用 FEM ソフトウェアの Abaqus/Standard に実装された連続体ソリッドシェル 要素によるマクロ板構造の解析を行い，この積層代理モデルの性能を検証する.
\end{abstract}

Key Words: Solid oxide fuel cell (SOFC), Numerical plate testing, Multi-scale analysis, Continuum solid-shell elements

\section{1. 緒言}

固体酸化物形燃料電池（Solid Oxide Fuel Cell : SOFC）は 高温条件下で然料となる水素と酸素を供給することによ って発電を行う。そのため, 構成部材は温度変化による 熱膨張とクリープ変形および電気化学反応に伴う還元膨 張によって機械的な劣化を起こすことが知られている 1 3). SOFC の機械的解析において還元膨張を考慮するに は，運転中の酸素ポテンシャルの非定常な変化を追従す る必要があるため, これまでの汎用 FEM ソフトウェア を用いた研究では熱膨張の考慮にとどまっており 4)7, 構成部材の材料内で発生する応力の評価に課題があった.

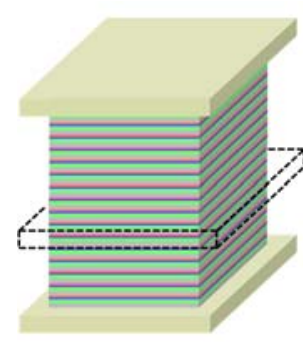

(a) Fuel cell stack

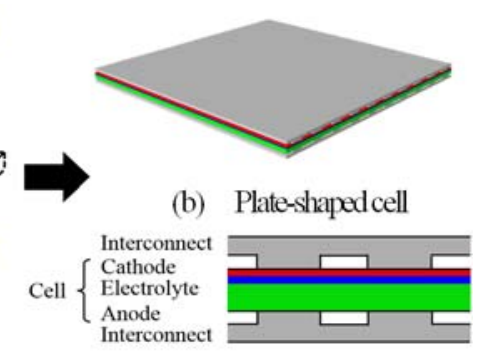

(c) Cross section of plate-shaped cell

図-1 SOFC の概要

そこで筆者らは，酸素ポテンシャル分布の経時変化を評 価しうる数理モデルを構築し，熱膨張，還元膨張および 
クリープ変形を含む非弾性的な変化を考慮した劣化挙動 の解析による評価手法を独自に開発してきた ${ }^{8}{ }^{811)}$.

SOFC の電池としての単位ユニットはセルと呼ばれ, アノード，カソードおよび電解質から構成される．通常, セルはインターコネクトを介して連結したセルスタック

(図-1 (a)）にすることによって, 高出力な発電を可能に している. セルの代表的な形状として, 面内に周期構造 を有する平板型セルがある（図-1 (b)および(c)）．板状デ バイス全体のマクロな挙動を把握するには，局所的な温 度および水素分圧の変化に伴う還元膨張によるミクロな 変形挙動を考慮しなければならない.しかし，これには 厚さ方向の分割を十分細かくする必要があり ${ }^{8-11)}$ ，この メッシュサイズを用いた板状デバイス全体の変形解析を 行うことは, 要素数や解析時間などの計算コストの観点 から現実的でない.

面内に周期的な微視的非均質性を有する構造物に関す るミクロ挙動を考慮したマクロ解析については, これま で様々な理論が提案されている ${ }^{12-10)}$. このうち, 板形状 のミクロ-マクロ連成解析のマルチスケール手法として, 面内に周期的な非均質性を有寸る複合板の数值平板試験 が開発され，線形弾性材料に対する適性が確認されてき た ${ }^{17}$, 18). しかし，この数值平板試験手法を非弾性材料に 適用し, マクロ非線形力学挙動を特徵づけたうえで, マ クロ解析を行うための方法論は未だ提案されていない.

そこで本研究では, 面内方向にのみ周期構造を有する SOFC の平板型セルのような，これまで検討されてこな かった非線形の板状デバイスにマルチスケール手法を適 用するために, 平板型セル内の面内に周期的な単一ミク 口構造を数值供試体と見立てて数值平板試験を実施し, そのマクロ非線形力学挙動を特徴づけるとともに，等価 なマクロ挙動を発現する均質な板を積み重ねた積層代理 モデルを新規に提案する. 具体的には, 積層構造を代理 モデルとして各層の材料特性を同定し, 汎用 FEM ソフ トウェア Abqus/Standard を用いて積層されたシェル要素 によるマクロ板構造の解析を行うことで，その性能を検 証する.

\section{2. マルチスケール板モデリング 17), 18)}

図-2 に示すような面内に周期的な非均質ミクロ構造 （以下，面内ユニット構造）を有する板状デバイスに対 する, マルチスケール解析手法について説明をする.こ こで, マクロ構造解析には積層板理論と類似の支配方程 式を採用する. 一方, ミクロ構造の解析には, 3 次元固 体要素の領域として静的つり合い問題を定義する.

マクロ構造に対して, 図-3を参照して厚板理論を採用 すると変位場は次式となる.

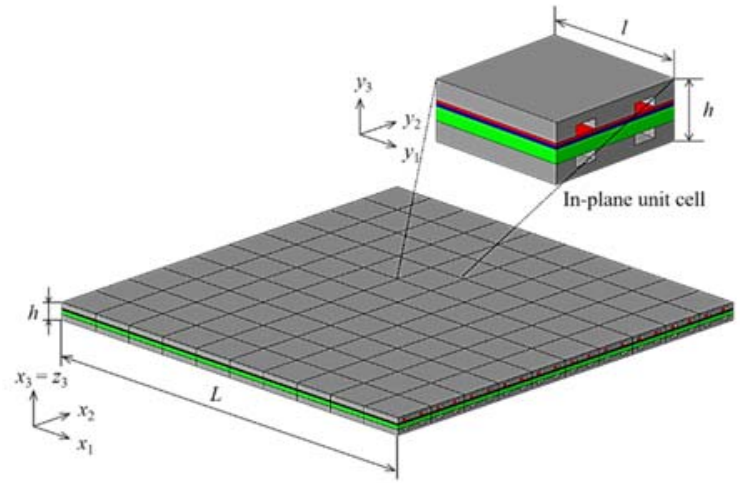

図-2 面内周期性を持つ非均質な板状デバイス

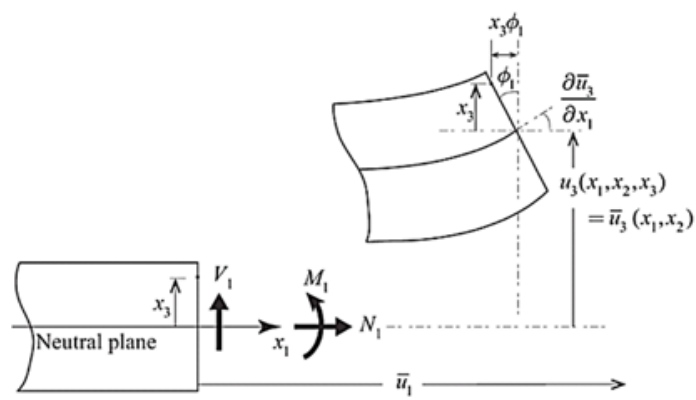

図-3 厚板理論の変位場

$$
\left\{\begin{array}{l}
u_{1}\left(x_{1}, x_{2}, x_{3}\right)=\bar{u}_{1}\left(x_{1}, x_{2}\right)-x_{3} \phi_{1}\left(x_{1}, x_{2}\right) \\
u_{2}\left(x_{1}, x_{2}, x_{3}\right)=\bar{u}_{2}\left(x_{1}, x_{2}\right)-x_{3} \phi_{2}\left(x_{1}, x_{2}\right) \\
u_{3}\left(x_{1}, x_{2}\right)=\bar{u}_{3}\left(x_{1}, x_{2}\right)
\end{array}\right.
$$

ここで， $\bar{u}_{i}$ は中心面上の変位および $\phi_{i}$ は断面の回転角 を表す．また， $N_{i}$ は板の断面に㗢く垂直応力， $M i$ は曲げ モーメントおよびV Vi面外せん断合成応力である. 式(1) より, マクロひずみ $\boldsymbol{E}$ は次のようになる.

$\left\{\begin{array}{c}E_{11} \\ E_{22} \\ E_{33} \\ 2 E_{12} \\ 2 E_{23} \\ 2 E_{31}\end{array}\right\}=\left\{\begin{array}{c}\frac{\partial \bar{u}_{1}}{\partial x_{1}}-x_{3} \frac{\partial \phi_{1}}{\partial x_{1}} \\ \frac{\partial \bar{u}_{2}}{\partial x_{2}}-x_{3} \frac{\partial \phi_{2}}{\partial x_{2}} \\ 0 \\ \frac{\partial \bar{u}_{1}}{\partial x_{2}}+\frac{\partial \bar{u}_{2}}{\partial x_{1}}-x_{3}\left(\frac{\partial \phi_{1}}{\partial x_{2}}-\frac{\partial \phi_{2}}{\partial x_{1}}\right) \\ \frac{\partial \bar{u}_{3}}{\partial x_{2}}-\phi_{2} \\ \frac{\partial \bar{u}_{3}}{\partial x_{1}}-\phi_{1}\end{array}\right\}=\left\{\begin{array}{c}\tilde{E}^{1}+x_{3} \tilde{E}^{4} \\ \tilde{E}^{2}+x_{3} \tilde{E}^{5} \\ 0 \\ \tilde{E}^{3}+x_{3} \tilde{E}^{6} \\ \tilde{E}^{7} \\ \tilde{E}^{8}\end{array}\right\}$

ここで， $\tilde{E}$ はマクロひずみと曲率を成分とするマク ロ一般化ひずみである. 図-4にマクロ一般化ひずみの各 変形モードを示す。

いま，面内ユニット構造として，図-5 に示すような $y_{1}$ 方向と $y_{2}$ 方向に面内周期性を持つ領域 $\left(-l_{1} / 2, l_{1} / 2\right) \times\left(-l_{2} /\right.$ $2, h / 2) \times(-h / 2, h / 2)$ の固体領域を考える. そして, ミク ロひずみをを次式のように定義する.

$$
\varepsilon=\tilde{z} \tilde{\boldsymbol{E}}+\partial_{y} \boldsymbol{u}^{*}
$$


ここで, $\boldsymbol{u}^{*}=\left\{u_{1}, u_{2}, u_{3},\right\}^{\mathrm{T}}$ は非均質性に起因するミク口擾 乱変位場であり, 全成分とも $y_{i}(i=1,2,3)$ の関数である. 図-5 の面内ユニット構造には，面内に周期的な非均質性 を仮定するため, 相対する境界面 $\partial Y_{[1]}$ と $\partial Y_{[-1]}, \partial Y_{[2]}$ と $\partial Y_{[-2]}$ 上の擾乱変位場には, 次式の周期拘束を課す.

$$
\left.\boldsymbol{u}_{j}^{*}\right|_{\partial Y_{[i]}}=\left.\boldsymbol{u}_{j}^{*}\right|_{\partial Y[-i]} \quad(i=1,2 ; j=1,2,3)
$$


ける行列であり， $\tilde{\boldsymbol{z}} \tilde{\boldsymbol{E}}$ は次式のように表される。

$$
\tilde{\boldsymbol{z}} \tilde{\boldsymbol{E}}=\left[\begin{array}{cccccccc}
1 & 0 & 0 & z_{3} & 0 & 0 & 0 & 0 \\
0 & 1 & 0 & 0 & z_{3} & 0 & 0 & 0 \\
0 & 0 & 0 & 0 & 0 & 0 & 0 & 0 \\
0 & 0 & 1 & 0 & 0 & z_{3} & 0 & 0 \\
0 & 0 & 0 & 0 & 0 & -z_{1} / 2 & 1 & 0 \\
0 & 0 & 0 & 0 & 0 & -z_{2} / 2 & 0 & 1
\end{array}\right]\left\{\begin{array}{c}
\tilde{E}^{1} \\
\tilde{E}^{2} \\
\tilde{E}^{3} \\
\tilde{E}^{4} \\
\tilde{E}^{5} \\
\tilde{E}^{6} \\
\tilde{E}^{7} \\
\tilde{E}^{8}
\end{array}\right\}
$$

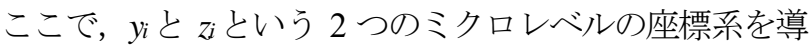
入したが， $y_{i}$ は均質化の過程で用いるものであり， $z_{i}$ は 板曲げ理論で用いる運動学的な座標系である. そのため $y_{i}$ と $z_{i}$ は互いに独立している.

なお，本研究では非弾性特性はクリープ特性のみを考 慮し，ミクロ全ひずみ $\boldsymbol{\varepsilon}(\boldsymbol{y})$ はミクロ弾性ひずみ $\boldsymbol{\varepsilon}^{\mathrm{e}}(\boldsymbol{y})$ とミ クロクリープひずみ $\varepsilon^{\mathrm{C}}(\boldsymbol{y})$ の和で表されるものとする.

以上より, $\sigma(y)$ をミクロ応力, $\boldsymbol{C}$ を構成材料の弾性係 数とした時, 面内ユニット構造に対するフォークト表記 の支配方程式はマクロおよびミクロひずみの定義を用い ると次式になる.

$$
\left\{\begin{array}{l}
\partial_{y}^{\mathrm{T}} \boldsymbol{\sigma}=\mathbf{0} \\
\boldsymbol{\sigma}=\boldsymbol{C} \boldsymbol{\varepsilon}^{\mathrm{e}}=\boldsymbol{C}\left(\boldsymbol{\varepsilon}-\boldsymbol{\varepsilon}^{\mathrm{c}}\right) \\
\boldsymbol{\varepsilon}=\tilde{\boldsymbol{z}} \tilde{\boldsymbol{E}}+\partial_{y} \boldsymbol{u}^{*} \\
\boldsymbol{u}^{*}: \text { In-plane Y-periodic }
\end{array}\right.
$$

一方，マクロ一般化応力 $\tilde{\boldsymbol{M}}$ は次式で定義する.

$$
\tilde{\boldsymbol{M}}=\frac{1}{l_{1} l_{2}} \int_{-h / 2}^{h / 2} z^{\mathrm{T}}\left(\int_{-l_{1} / 2}^{l_{1} / 2} \int_{-l_{2} / 2}^{l_{2} / 2} \sigma\left(y_{1}, y_{2}, y_{3}\right) d y_{2} d y_{1}\right) d y_{3}
$$

このマクロ一般化応力の成分は $O-x_{1} x_{2} x_{3}$ からなるマクロ 座標系において, $x_{1}$ 面と $x_{2}$ 面の垂直合応力 $\tilde{N}_{11}, \tilde{N}_{22}$ と面 外合せん断応力 $\tilde{N}_{12}, x_{1}$ 面と $x_{2}$ 面に関する曲げモーメン ト $\tilde{M}_{11}, \tilde{M}_{22}$ とねじりモーメント $\tilde{M}_{12}$ ，および $x_{1}$ 面とx 2 面 の面外せん断合応力 $\tilde{V}_{23}, \tilde{V}_{13}$ によって, 次式のように表 される.


Mode 2

Mode 3
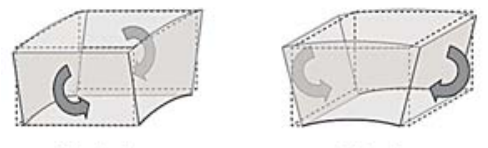

Mode 5
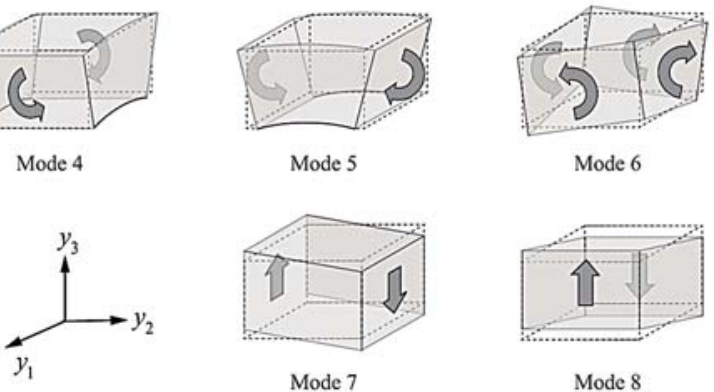

Mode 7

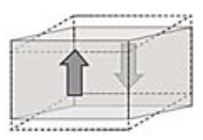

Mode 8



図-5＼cjkstart板状デバイスの面内ユニット構造

$\tilde{\boldsymbol{M}}=\left\{\begin{array}{llllllll}\tilde{N}_{11} & \tilde{N}_{22} & \tilde{N}_{12} & \tilde{M}_{11} & \tilde{M}_{22} & \tilde{M}_{12} & \tilde{V}_{23} & \tilde{V}_{13}\end{array}\right\}^{\mathrm{T}}$

面内ユニット構造が線形弾性体のみで構成される場合, マクロ一般化ひずみと一般化応力の間には次の関係式が 成り立つ。

$$
\tilde{\boldsymbol{M}}=\tilde{\boldsymbol{D}} \tilde{\boldsymbol{E}}
$$

ここで， $\tilde{\boldsymbol{D}}$ は均質化板剛性であり，その成分は次のよ うになる。

$\tilde{\boldsymbol{D}}=\left[\begin{array}{lll}\boldsymbol{A} & \boldsymbol{B} & \boldsymbol{K} \\ \boldsymbol{B}^{\mathrm{T}} & \boldsymbol{D} & \boldsymbol{L} \\ \boldsymbol{K}^{\mathrm{T}} & \boldsymbol{L}^{\mathrm{T}} & \boldsymbol{H}\end{array}\right]$

$=\left[\begin{array}{lll|lll|ll}A_{11} & A_{12} & A_{13} & B_{11} & B_{12} & B_{13} & K_{11} & K_{12} \\ A_{12} & A_{22} & A_{23} & B_{12} & B_{22} & B_{23} & K_{12} & K_{22} \\ A_{13} & A_{23} & A_{33} & B_{13} & B_{23} & B_{33} & K_{13} & K_{23} \\ \hline B_{11} & B_{12} & B_{13} & D_{11} & D_{12} & D_{13} & L_{11} & L_{12} \\ B_{12} & B_{22} & B_{23} & D_{12} & D_{22} & D_{23} & L_{12} & L_{22} \\ B_{13} & B_{23} & B_{33} & D_{13} & D_{23} & D_{33} & L_{13} & L_{23} \\ \hline K_{11} & K_{12} & K_{13} & L_{11} & L_{12} & L_{13} & H_{11} & H_{12} \\ K_{12} & K_{22} & K_{23} & L_{12} & L_{22} & L_{23} & H_{12} & H_{22}\end{array}\right]$


この均質化板剛性を求めるには，マクロ一般化ひずみ の各変形モードにおいて式(6)を解き, 得られたミクロ 応力の成分を式(7)に適応してマクロ一般化応力を算出 する. それにより, 各変形パターンに対応寸る均質化板 剛性の成分を求めることができる，このようにしてマク 口の板剛性を求めるミク口解析を「数值平板特性試験」 と呼んでいる.

ただし，クリープ変形を示寸ような非弾性材料を面内 ユニット構造の構成材料として用いる場合には，上記の ような均質化板剛性 $\tilde{\boldsymbol{D}}$ を用いたマクロ一般化ひずみ $\tilde{\boldsymbol{E}}$ と一般化応力 $\tilde{\boldsymbol{M}}$ の線形関係式は得られない. その代わ り増分解法に伴って数值的に算出される離散的な点の集 合が描く非線形な曲線が得られるのみであり，それに対 応する非線形な構成則関数を決定することはできない. すなわち，式(7)はマクロ一般化ひずみ $\tilde{\boldsymbol{E}}$ の陰的な関数 であり，一般化応力 $\tilde{\boldsymbol{M}}$ との関係は陽的に決定できない. このため本研究では，8つの変形モードを表すマクロ一 般化ひずみをデータとして，ミクロ境界值問題の式(6) を解き，式(7)に対応するマクロな一般化応力応答を各 変形レベルに応じて算出する，そして，そこで得られた 非線形マクロ力学挙動と等価な挙動を発現しうる積層構 造の代理ミクロモデルを設定し，各層の材料特性を同定 したうえで, マクロ解析を行うミクロ-マクロ分離型解 法を提案する.

\section{3. 数值平板特性試験 ${ }^{17)}$}

ここでは, 数值平板特性試験の具体的な方法を述べる。 図-5 のミクロ構造の面内ユニット構造において, ミク 口変位 $\boldsymbol{w}=\left\{w_{1}, w_{2}, w_{3}\right\}^{\mathrm{T}}$ は次のように表される.

$\left\{\begin{array}{l}w_{1}=\left(\tilde{E}^{1}+z_{3} \tilde{E}^{4}\right) y_{1}+\left(\tilde{E}^{3}+z_{3} \tilde{E}^{6}\right) \frac{y_{2}}{2}+\left(\tilde{E}^{8}-\frac{z_{2}}{2} \tilde{E}^{6}\right) y_{3}+u_{1}^{*} \\ w_{2}=\left(\tilde{E}^{3}+z_{3} \tilde{E}^{6}\right) \frac{y_{1}}{2}+\left(\tilde{E}^{2}+z_{3} \tilde{E}^{5}\right) y_{2}+\left(\tilde{E}^{7}-\frac{z_{1}}{2} \tilde{E}^{6}\right) y_{3}+u_{2}^{*} \\ w_{3}=\left(\tilde{E}^{8}-\frac{z_{2}}{2} \tilde{E}^{6}\right) y_{1}+\left(\tilde{E}^{7}-\frac{z_{1}}{2} \tilde{E}^{6}\right) y_{2}\end{array}\right.$

相対する境界面 $\partial Y_{[ \pm 1]}$ および $\partial Y_{[ \pm 2]}$ において, 周期性 を満足させるには, 式(11)のミクロ変位 $\boldsymbol{w}$ に関して次の ような拘束条件を課す必要がある。

$$
\left\{\begin{array}{l}
q_{1}^{[1]} \equiv w_{1}^{[1]}-w_{1}^{[-1]}=\left(\tilde{E}^{1}+z_{3} \tilde{E}^{4}\right) l_{1} \\
q_{2}^{[1]} \equiv w_{2}^{[1]}-w_{2}^{[-1]}=\frac{1}{2}\left(\tilde{E}^{3}+z_{3} \tilde{E}^{6}\right) l_{1} \\
q_{3}^{[1]} \equiv w_{3}^{[1]}-w_{3}^{[-1]}=\left(\tilde{E}^{8}-\frac{z_{2}}{2} \tilde{E}^{6}\right) l_{1}
\end{array}\right.
$$

$$
\left\{\begin{array}{l}
q_{1}^{[2]} \equiv w_{1}^{[2]}-w_{1}^{[-2]}=\frac{1}{2}\left(\tilde{E}^{3}+z_{3} \tilde{E}^{6}\right) l_{2} \\
q_{2}^{[2]} \equiv w_{2}^{[2]}-w_{2}^{[-2]}=\left(\tilde{E}^{2}+z_{3} \tilde{E}^{5}\right) l_{2} \\
q_{3}^{[2]} \equiv w_{3}^{[2]}-w_{3}^{[-2]}=\left(\tilde{E}^{7}-\frac{z_{1}}{2} \tilde{E}^{6}\right) l_{2}
\end{array}\right.
$$

ここで, $q_{j}^{[i]}$ は相対変位, 各変数の添え字 $[ \pm i]$ は境界面 $\partial Y_{[ \pm i]}$ 上の值を表している.

実際の解析において, 汎用 FEM ソフトウェアを用い る場合，相対変位を与える外部節点（制御節点）を新た に導入し, 式(12)および(13)の拘束条件を多点拘束として 与えることになる. 例えば, 面内ユニット構造に対して Model の $y_{1}$ 方向に単軸引張りの変形を与える時, マクロ 一般化ひずみ $\tilde{\boldsymbol{E}}$ は $\tilde{E}^{1}$ 成分にのみ值 $\hat{E}$ を有する. すなわ ち，次式のように設定される.

$$
\begin{aligned}
& \left\{\begin{array}{llllllll}
\tilde{E}^{1} & \tilde{E}^{2} & \tilde{E}^{3} & \tilde{E}^{4} & \tilde{E}^{5} & \tilde{E}^{6} & \tilde{E}^{7} & \tilde{E}^{8}
\end{array}\right\} \\
& =\left\{\begin{array}{llllllll}
\hat{E} & 0 & 0 & 0 & 0 & 0 & 0 & 0
\end{array}\right\}
\end{aligned}
$$

式(14)を式(12)および(13)に適用すると次のような拘束条 件を得る。

$$
\begin{gathered}
\left\{\begin{array}{l}
q_{1}^{[1]} \equiv w_{1}^{[1]}-w_{1}^{[-1]}=\hat{E} l_{1} \\
q_{2}^{[1]} \equiv w_{2}^{[1]}-w_{2}^{[-1]}=0 \\
q_{3}^{[1]} \equiv w_{3}^{[1]}-w_{3}^{[-1]}=0
\end{array}\right. \\
\left\{\begin{array}{l}
q_{1}^{[2]} \equiv w_{1}^{[2]}-w_{1}^{[-2]}=0 \\
q_{2}^{[2]} \equiv w_{2}^{[2]}-w_{2}^{[-2]}=0 \\
q_{3}^{[2]} \equiv w_{3}^{[2]}-w_{3}^{[-2]}=0
\end{array}\right.
\end{gathered}
$$

図-5に示寸ような $\partial Y_{[1]}$ 面上の節点 $\mathrm{D}$ と $\partial Y_{[-1]}$ 面上の節 点 $\mathrm{E}, \partial Y_{[2]}$ 面上の節点 $\mathrm{F}$ と $\partial Y_{[-2]}$ 面上の節点 $\mathrm{G}$ とし, それぞれの面に対応した制御節点を $\mathrm{M}, \mathrm{N}$ とする面内ユ ニット構造を考える. このモデルに対し，式(15)および (16)の境界条件を与える場合, 節点 $\mathrm{D}, \mathrm{E}$ および節点 $\mathrm{F}$, $\mathrm{G}$ とそれぞれの制御節点 $\mathrm{M}, \mathrm{N}$ には，次式のような拘束 条件を与えることとなる.

$$
\begin{aligned}
& \left\{\begin{array}{l}
w_{1}^{\mathrm{D}}-w_{1}^{\mathrm{E}}=q_{1}^{\mathrm{M}}=\hat{E} l_{1} \\
w_{2}^{\mathrm{D}}-w_{2}^{\mathrm{E}}=q_{2}^{\mathrm{M}}=0 \\
w_{3}^{\mathrm{D}}-w_{3}^{\mathrm{E}}=q_{3}^{\mathrm{M}}=0
\end{array}\right. \\
& \left\{\begin{array}{l}
w_{1}^{\mathrm{F}}-w_{1}^{\mathrm{G}}=q_{1}^{\mathrm{N}}=0 \\
w_{2}^{\mathrm{F}}-w_{2}^{\mathrm{G}}=q_{2}^{\mathrm{N}}=0 \\
w_{3}^{\mathrm{F}}-w_{3}^{\mathrm{G}}=q_{3}^{\mathrm{N}}=0
\end{array}\right.
\end{aligned}
$$

他の変形モードにおいても，同様の方法で拘束条件を 決定することができる ${ }^{17}$.

一方, マクロ一般化応力は式(7)のような体積積分に 
よって定義されているが，これを表面積分に変換すると 次式になる.

$$
\begin{gathered}
\tilde{N}_{\alpha \beta}=\frac{1}{l_{\gamma}} \int_{\partial Y[\alpha]} t_{\beta}^{[\alpha]} d S=\frac{\tilde{F}_{\alpha \beta}}{l_{\gamma}} \quad \text { (Mode1 Mode3) } \\
\tilde{M}_{\alpha \beta}=\frac{1}{l_{\gamma}} \int_{\partial Y[\alpha]} z_{3} t_{\beta}^{[\alpha]} d S=\frac{\tilde{G}_{\alpha \beta}}{l_{\gamma}} \quad \text { (Mode4 and Mode5) } \\
\tilde{M}_{12}=\frac{1}{2 l_{2}} \int_{\partial Y[1]} z_{3}^{\left[t_{2}^{[1]}\right.} d S+\frac{1}{2 l_{1}} \int_{\partial Y[2]}^{Z_{3} t_{1}^{[2]} d S} \\
-\frac{1}{2 h} \int_{\partial Y[[2]} z_{1}^{[2]} d S-\frac{1}{2 h} \int_{\partial Y[1]}^{Z_{2} t_{3}^{[1]} d S} \\
=\frac{\tilde{G}_{12}^{[1]}}{2 l_{2}}+\frac{\tilde{G}_{21}^{[2]}}{2 l_{1}}-\frac{\tilde{G}_{23}^{[2]}}{2 h}-\frac{\tilde{G}_{13}^{[1]}}{2 h} \quad \text { (Mode6) } \\
\tilde{V}_{\alpha 3}=\frac{1}{l_{\gamma}} \int_{\partial Y[\alpha]} t_{3}^{[\alpha]} d S=\frac{\tilde{F}_{\alpha 3}}{l_{\gamma}} \quad \text { (Mode7 and Mode8) }
\end{gathered}
$$

ここで, $\gamma \neq \alpha(=1,2), \quad t_{\beta}^{[\alpha]}$ は境界面 $\partial Y_{[\alpha]}(\alpha=1,2)$ に おける単位外向き法線べクトル $\boldsymbol{n}$ を有する応力ベクトル の $\beta$ 方向成分であり, 式(7)の応力テンソル成分 $\sigma_{\alpha j}$ によ って次のように表される.

$$
t_{\beta}^{[\alpha]}=\sigma_{\alpha j} n_{j}^{[\alpha]} \quad(\beta=1,2 ; j=1,2,3)
$$

沉用 FEM ソフトウェアを用いた解析においては，拘 束条件に関する等価節点力との関係から一般化応力を得 ることができる． $l_{\gamma} \tilde{N}_{\alpha \beta}, l_{\gamma} \tilde{M}_{\alpha \beta}$ および $l_{\gamma} \tilde{V}_{\alpha 3}$ は境界面 $\partial Y_{[\alpha]}$ 上の全節点の等価節点力の総和に等しく, 制御節 点に作用する等価節点力あるいはモーメントは，すべて の多点拘束の条件式による節点反力の総和に等しい. し たがって, 制御節点の節点反力 $\tilde{F}_{\alpha \beta}$, あるいはモーメン 卜反力 $\tilde{G}_{\alpha \beta}$ によって，一般化応力は次式のようになる.

$$
\begin{aligned}
\tilde{\boldsymbol{M}}= & \left\{\begin{array}{llllllll}
\tilde{N}_{11} & \tilde{N}_{22} & \tilde{N}_{12} & \tilde{M}_{11} & \tilde{M}_{22} & \tilde{M}_{12} & \tilde{V}_{23} & \tilde{V}_{13}
\end{array}\right\}^{\mathrm{T}} \\
= & \left\{\begin{array}{llllll}
\frac{\tilde{F}_{11}}{l_{2}} & \frac{\tilde{F}_{22}}{l_{1}} & \frac{\tilde{F}_{12}}{l_{2}} & \frac{\tilde{G}_{11}}{l_{2}} & \frac{\tilde{G}_{22}}{l_{1}} \\
& \frac{1}{2}\left(\frac{\tilde{G}_{12}^{[1]}}{l_{2}}+\frac{\tilde{G}_{21}^{[2]}}{l_{1}}+\frac{\tilde{G}_{23}^{[2]}}{h}+\frac{\tilde{G}_{13}^{[1]}}{h}\right) & \frac{\tilde{F}_{23}}{l_{1}} & \frac{\tilde{F}_{13}}{l_{2}}
\end{array}\right\}^{\mathrm{T}}
\end{aligned}
$$

\section{4. 平板型セルの数値平板特性試験}

図-6に示寸，ランタンストロンチウムコバルトフェラ イト $\left((\mathrm{La}, \mathrm{Sr})(\mathrm{Co}, \mathrm{Fe}) \mathrm{O}_{3}: \mathrm{LSCF}\right)$ のカソード，8mol\%イット リア安定化ジルコニア（8mol\% Ytria Stabilized Zirconia : 8YSZ）の電解質, ニッケル - イットリア安定化ジルコ ニア（Ni-Ytria Stabilized Zirconia:Ni-YSZ）のアノード，カ

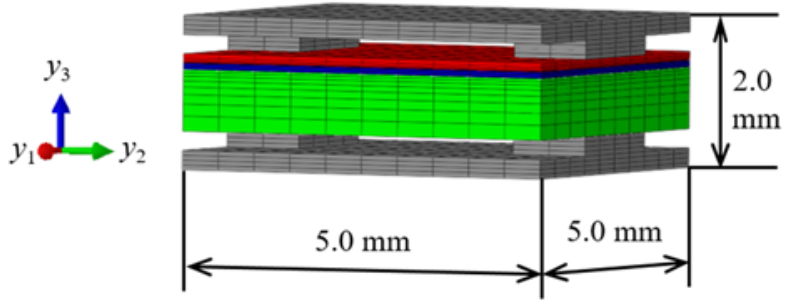

図-6 平板型セルの面内ユニット構造

(モデル 1)

表-1 材料定数 11)

\begin{tabular}{c|c|c}
\hline & $\begin{array}{c}\text { Young's } \\
\text { Modulus [MPa] }\end{array}$ & $\begin{array}{c}\text { Poisson's ratio } \\
{[-]}\end{array}$ \\
\hline Interconnect & $1.35 \times 10^{5}$ & 0.35 \\
\hline Cathode & $1.70 \times 10^{5}$ & 0.25 \\
\hline Electrolyte & $1.50 \times 10^{5}$ & 0.4 \\
\hline Anode & $9.00 \times 10^{4}$ & 0.3 \\
\hline
\end{tabular}

ルシウムを添付したランタンクロマイト $\left(\mathrm{La}(\mathrm{Ca}) \mathrm{CrO}_{3}\right.$ : LCCr）のインターコネクトからなる $l_{1}=h_{2}=5.0 \mathrm{~mm}, t=$ $2.0 \mathrm{~mm}$ のアノードサポート型 SOFC の面内ユニット構造 を用いてモードごとの数值平板特性試験を行った. 各材 料の厚さは，上下のインターコネクトが $0.5 \mathrm{~mm}$, カソー ドが $0.12 \mathrm{~mm}$ ，電解質が $0.08 \mathrm{~mm}$ ，アノードが $0.8 \mathrm{~mm}$ であ る.

有限要素メッシュには 3 次元 8 節点六面体要素を使用 し, 節点数が 3689, 要素数が 2728 である. 各変形モ一 ドにおいて，このモデルに $2000 \mathrm{sec}$ かけて $\hat{E}=0.04$ とな るまで漸増的に負荷し，その後 $2000 \mathrm{sec}$ かけて除荷を行 う。ここで, インターコネクト, カソードおよび電解質 はセラミックスのため等方弾性体とする. 一方, アノー ドはセラミックスと金属を焼結して生成した複合材であ るため, クリープ特性を有する非弾性体である. 本研究 では，次式で与えられるクリープひずみの発展則を用い てその特性を表現する.

$$
\dot{\bar{\varepsilon}}^{\mathrm{C}}=k|\bar{\sigma}|^{n} t^{m}
$$

ここで， $\dot{\bar{\varepsilon}}^{\mathrm{C}}$ は相当クリープ速度， $\bar{\sigma}$ は von Mises 相当応 力， $t$ は時間，および $k, n, m$ は材料定数であり, $k=1.76$ $\times 10^{-7} \mathrm{~m}^{2 n} /\left(\mathrm{s}^{m+1} \mathrm{~N}^{n}\right), n=1.1, \quad m=-0.5$ とした. また, それぞ れの材料の弾性特性を表-1 に示寸 ${ }^{11}$.

図-7に各モードにおける $\hat{E}$ が 0.04 に達したときの変形 形状を示す．コンターはvonMises相当応力である。この 


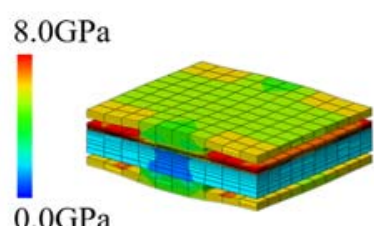

(a) Mode 1

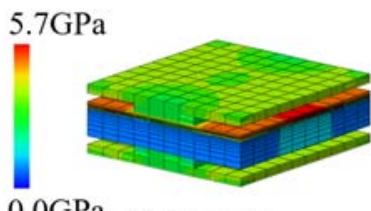

(c) Mode 3

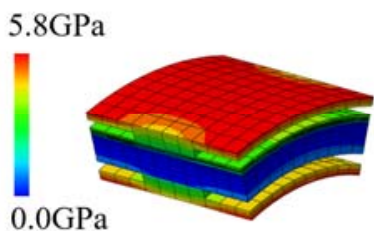

(e) Mode 5

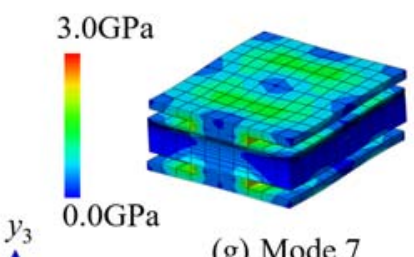

(g) Mode 7



(b) Mode 2

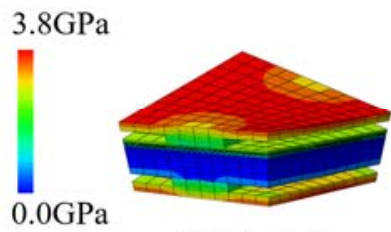

(f) Mode 6
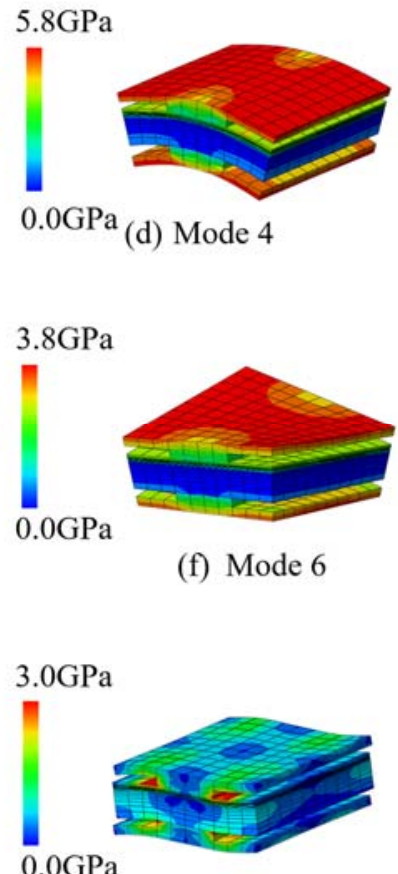

(h) Mode 8

図-7各モードの変形形状

(von Mises 相当応力分布)

図から, 各モードの変形形状が適切に表現されているこ とが確認できる.

図-8に各モードの一般化応力 - 一般化ひずみ曲線を, 弾性特性のみを考慮した場合の線形応答と併せて示す。 今回のような平板型セルの場合, 非弾性特性が顕著に現 れていることが確認できる（図-8(a)，(b)，(e)）。また， 引張り, 曲げおよび面外せん断の変形モードでは, 方向 によらず一致した曲線となっている（図-8(a)，(c)，(e)）。 面内ユニット構造の変形形状では, 方向毎に応力分布が それぞれ異なる現れ方をしているが(図-7), 図-8 より マクロ的には，等方的な挙動であると言える.

また, 図-8には非線形性が顕著に現れている変形モ一 ドとごく僅かにしか現れない変形モードがある。この違 いを確認するために, 図-9に Mode1 と Mode4の $\hat{E}$ が 0.04 のときのアノード材のみの変形形状を示す．コンターは von Mises 相当応力を表している. Mode4 はアノードが中 立面に近いため, 発生している応力值が Mode1 と比べて 小さい. したがって, Mode4 においてアノードのクリー

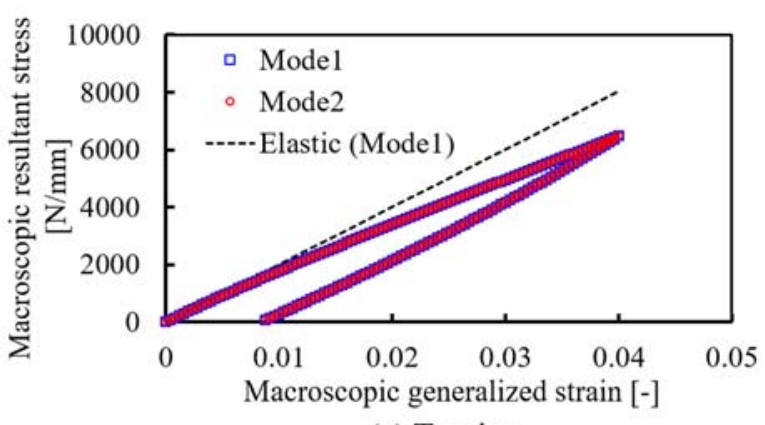

(a) Tension

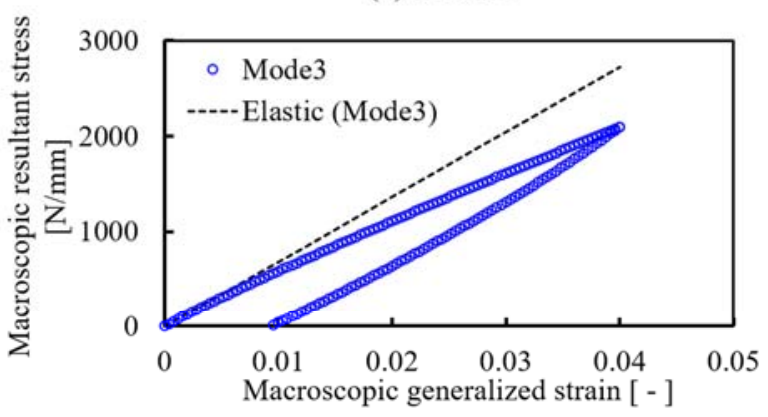

(b) In-plane shear

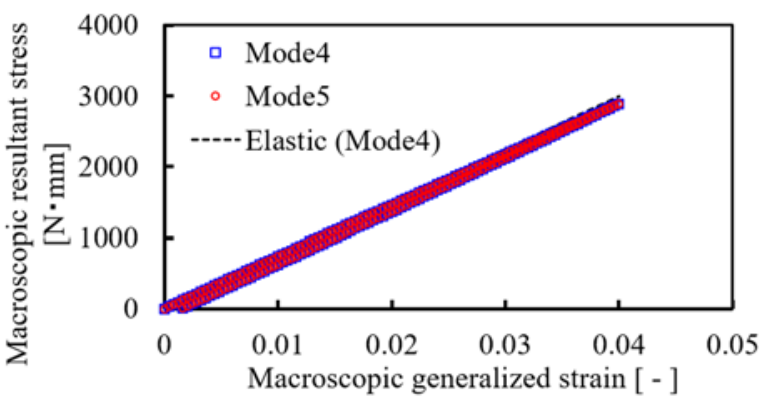

(c) Bending

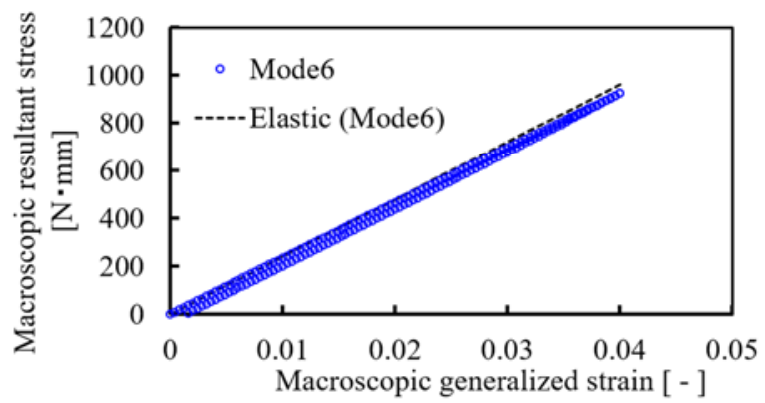

(d) Torsion



(e) Out-of-plane shear

図-8一般化応力 - 一般化ひずみ曲線 (O, $\square$ : 非線形応答を考慮, - - - : : 線形応答のみ) 

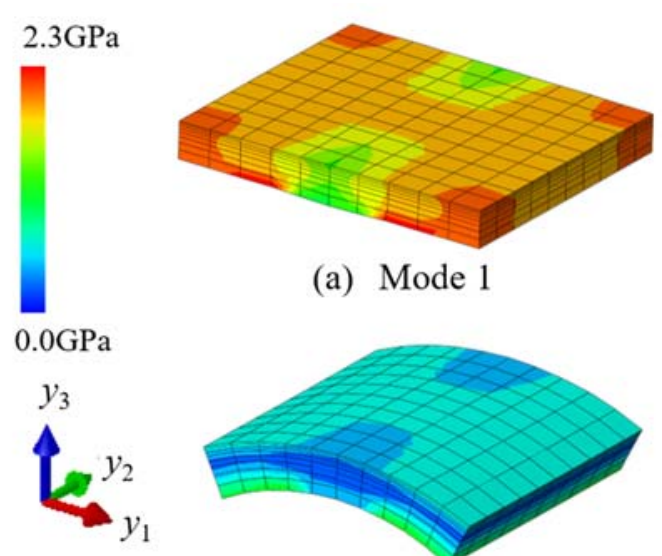

(a) Mode 1

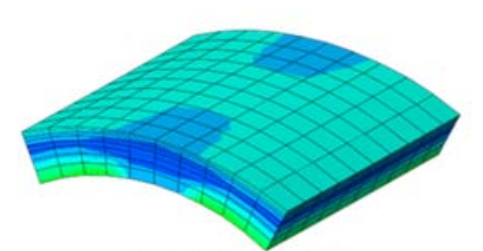

(b) Mode 4

図-9 アノードの変形形状（von Mises 相当応力分布）

プの影響は, Model のそれに比べて小さいと考えられる. これは, Mode5 の $y_{2}$ 方向の曲げや Mode6の㸚じりでも同 じことがいえる. 以上より，今回のようなアノードサポ 一ト型の平板型セルのような場合，曲げおよびねじりの 変形モードでは非線形性が現れにくいと考えられる.

\section{5. 代理モデルを用いたマクロ解析}

平板型 SOFC には，図-10 に示寸ような燃料の流路が 1 方向となる燃料電池を用いることがある。ここでは，こ の面内ユニット構造を用いた数值平板特性試験を行い, 同等のマクロ平板の板剛性を与えうる積層構造の代理モ デルを提示する. そして，この積層代理モデルの各層の 材料パラメータを最適化手法を適用して決定したうえで, 積層シェル要素によるマク口解析を行い, 本手法の有効 性を検証する.

\section{（1）数值平板特性試験}

4 章と同じ材料である LSCF のカソード，8YSZ の電解 質, Ni-YSZ のアノード，LCCr のインターコネクトから なる $l_{1}=k_{2}=5.0 \mathrm{~mm}, t=2.0 \mathrm{~mm}$ のアノードサポート型 SOFC の面内ユニット構造を用いる. 各材料の厚さは, 上下のインターコネクトが $0.5 \mathrm{~mm}$, カソードが $0.12 \mathrm{~mm}$, 電解質が $0.08 \mathrm{~mm}$, アノードが $0.8 \mathrm{~mm}$ であり, 流路の断 面のサイズは $0.5 \times 1.5 \mathrm{~mm}^{2}$ である.

有限要素メッシュには 3 次元 8 節点六面体要素を使用 する. また, 温度および水素分圧の変化に起因する局所 変形の解析が可能な要素サイズにするために, カソード と電解質の厚さ方向における分割数を 5 とし，ユニット 構造全体の節点数を 7205 , 要素数を 5600 とした.

このモデルに，各モードにおいて 2000sec かけて $\hat{E}=0.04$ になるまで漸増的に負荷し，その後 2000 sec か けて除荷を行う，材料定数やクリープパラメータについ

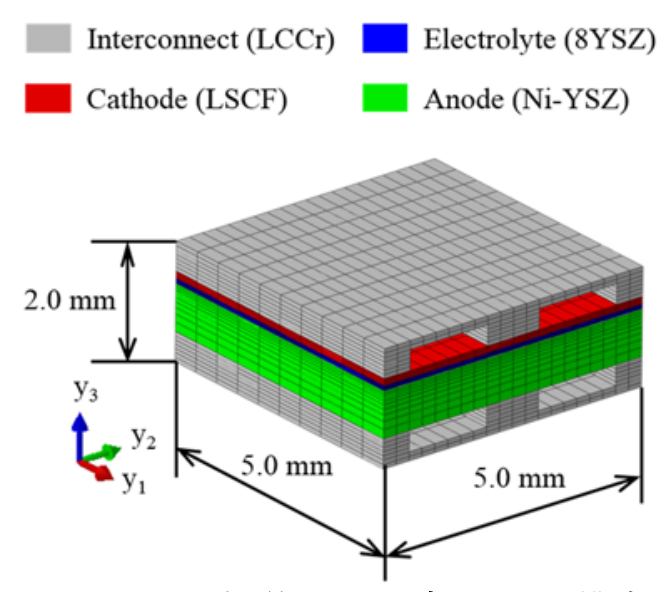

図-10 平板型セルの面内ユニット構造

(モデル 2)



(a) Mode 1

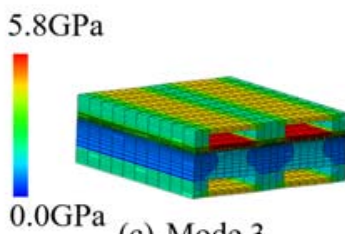

(c) Mode 3

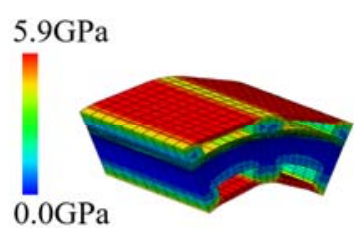

(e) Mode 5

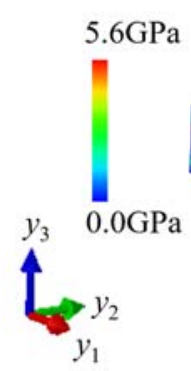

\section{図-11 各モードの変形形状 \\ (von Mises 相当応力分布)}

ては，4章の值を用いる.

図-11 に $\hat{E}=0.04$ における各モードの変形形状を示す. ここで，コンターは von Mises 相当応力を表している.

Mode1, Mode4, Mode8 の $y_{1}$ 方向に関する変形において は，ユニットモデルが一様に変形していることが確認で きる(図-11(a)，(d)，(h)）。これに対し，Mode2，Mode5, Mode7 の $y_{2}$ 方向に関する変形では, インターコネクトの 流路部分の厚さが薄く, 大きな変形が生じていることが 
表-2＼cjkstart面内ユニット構造の板剛性（モデル 2）

\begin{tabular}{lll|l}
\hline In-plane normal & $A_{11}$ & {$[\mathrm{~N} / \mathrm{mm}]$} & $2.01 \times 10^{5}$ \\
\hline In-plane normal & $A_{22}$ & {$[\mathrm{~N} / \mathrm{mm}]$} & $1.79 \times 10^{5}$ \\
\hline In-plane coupling & $A_{12}$ & {$[\mathrm{~N} / \mathrm{mm}]$} & $5.73 \times 10^{4}$ \\
\hline In-plane shear & $A_{33}$ & {$[\mathrm{~N} / \mathrm{mm}]$} & $6.30 \times 10^{4}$ \\
\hline Bending & $D_{11}[\mathrm{~N} \cdot \mathrm{mm}]$ & $7.04 \times 10^{4}$ \\
\hline Bending & $D_{22}[\mathrm{~N} \cdot \mathrm{mm}]$ & $5.86 \times 10^{4}$ \\
\hline Coupled bending & $D_{12}[\mathrm{~N} \cdot \mathrm{mm}]$ & $2.15 \times 10^{3}$ \\
\hline Torsion & $D_{33}[\mathrm{~N} \cdot \mathrm{mm}]$ & $1.87 \times 10^{4}$ \\
\hline Out of plane shear & $H_{11}$ & {$[\mathrm{~N} / \mathrm{mm}]$} & $2.75 \times 10^{4}$ \\
\hline Out of plane shear & $H_{22}$ & {$[\mathrm{~N} / \mathrm{mm}]$} & $3.82 \times 10^{4}$ \\
\hline
\end{tabular}

分かる (図-11 (b), (e), (g)) .

また, 図-12 に各モードの一般化応力 - 一般化ひずみ 曲線を示す．どのモードにおいても非線形性が現れてい ることが分かる．また，引張り，曲げ，面外せん断の変 形モードではそれぞれ異方性が現れていることが確認で きる，これは，図-11 で示した変形形状の違いが，マク 口力学挙動の異方性に反映されたものと考えられる.

この面内ユニット構造について線形弾性特性のみを考 慮した数值平板特性試験の結果, 得られる板剛性を表-2 に示寸.

\section{(2) 代理モデルの導入}

平板型セルを解析するために，5.(1)節で用いた面内ユ ニット構造と同様のマクロ力学挙動を発現しうる代理モ

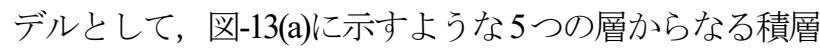
構造を導入する. ここで, アノード，カソード，電解質 については, 元の面内ユニット構造とこの代理モデルが 有する各層の材料, 厚さと同一に設定し，材料定数も表 -1 に示寸值を使用寸る. 一方, インターコネクトは図12 より, 直交異方性弾性を示寸単一の材料定数からな る層に置き換える，そして，この代理モデルに対して行 う数值平板特性試験の結果が, 前節の数值平板特性試験 の結果と整合するように最適化手法を用いてインターコ ネクトに設定した層の材料のパラメータを同定する. た だし，インターコネクトには非弾性効果が含まれない線 形弾性材料と仮定しているので, 本解析例では, 線形弾 性パラメータのみを同定対象とし，非弾性効果であるア ノードのクリープ特性を除いた数值平板特性試験の結果 と比較した.

本研究では, 材料パラメータ同定を行うための最適化 手法には，遺伝的アルゴリズムの一つである実数值 GA

（Real-coded genetic algorithm：RGA）19)-21)を採用し，図-



(a) Tension

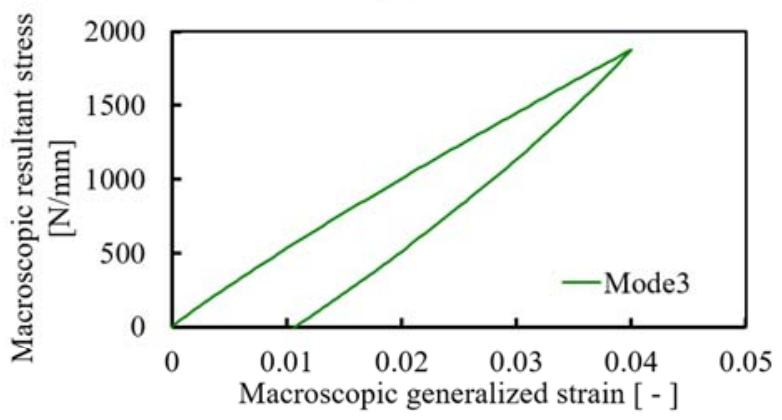

(b) In-plane shear

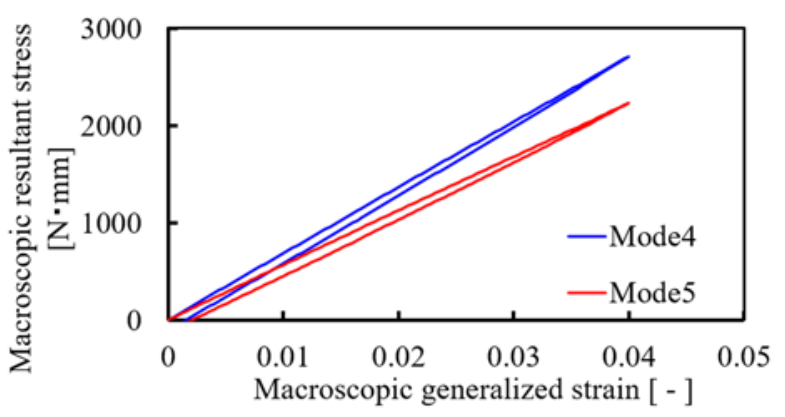

(c) Bending

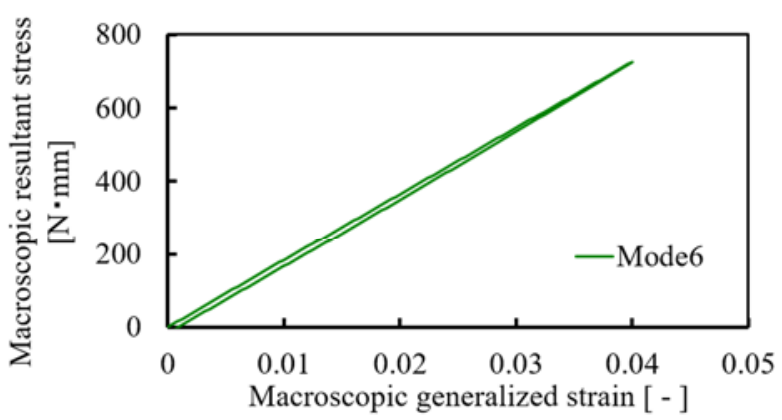

(d) Torsion

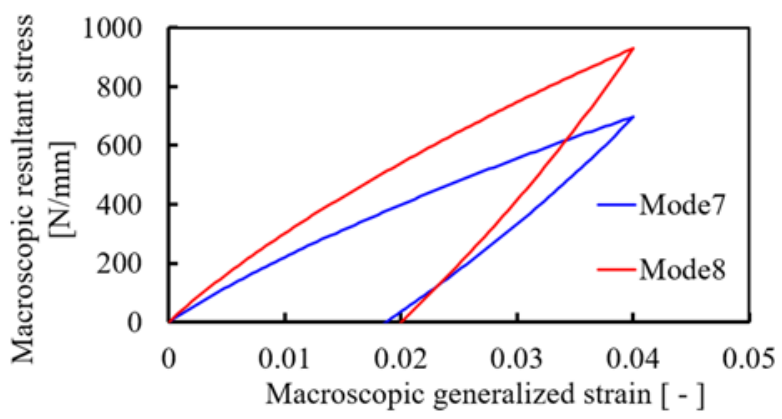

(e) Out-of-plane shear

図-12 一般化応力 - 一般化ひずみ曲線 


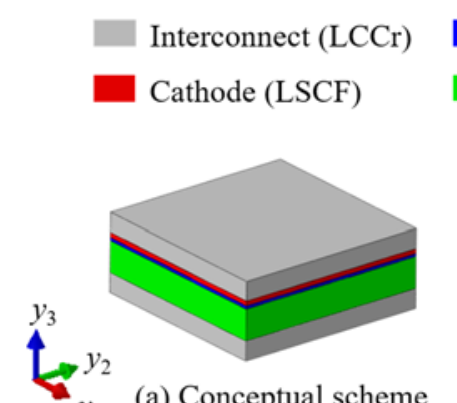

(a) Conceptual scheme
Electrolyte (8YSZ)

Anode (Ni-YSZ)

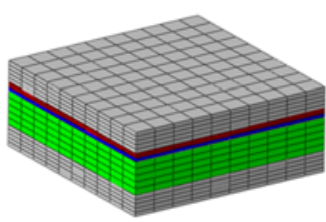

(b) Analysis model

図-13同定モデルの概念図と解析モデル

13(b)のように分割したソリッド要素を使用した.

最適化計算の結果, 積層代理モデル内のインターコネ クトの材料として仮定した直交異方性弾性の岡性マトリ ックス $\boldsymbol{C}_{\boldsymbol{I}}$ の成分は次のように決定された.

$$
\boldsymbol{C}_{I}=\left[\begin{array}{cccccc}
C_{1111} & C_{1122} & C_{1133} & 0 & 0 & 0 \\
& C_{2222} & C_{2233} & 0 & 0 & 0 \\
& & C_{3333} & 0 & 0 & 0 \\
& & & C_{1212} & 0 & 0 \\
& \text { Sym } & & & C_{1313} & 0 \\
& & & & & C_{2323}
\end{array}\right]
$$

$C_{1111}=1.16 \times 10^{5} \mathrm{MPa}, \quad C_{1122}=5.34 \times 10^{4} \mathrm{MPa}$,

$C_{2222}=9.46 \times 10^{4} \mathrm{MPa}, \quad C_{1133}=6.30 \times 10^{4} \mathrm{MPa}$,

$C_{2233}=6.37 \times 10^{4} \mathrm{MPa}, \quad C_{3333}=1.32 \times 10^{5} \mathrm{MPa}$,

$C_{1212}=2.30 \times 10^{4} \mathrm{MPa}, \quad C_{1313}=9.16 \times 10^{3} \mathrm{MPa}$,

$$
C_{2323}=5.22 \times 10^{3} \mathrm{MPa}
$$

また，図-14 に同定結果の一般化応力 - 一般化ひずみ 曲線を示す．設定した代理モデルと同定した材料パラメ 一タが有効に機能していることが分かる．図-14(c)およ び(d)では若干の誤差が見られるが，次節で取り扱うモ デルサイズでは十分な精度の結果が得られるため, 本研 究ではこの值を採用する.

\section{(3) 平板型セルのマクロ解析}

5.(2)節で設定した代理モデルの平板型セルのマクロ解 析により，提案した計算手法の精度検証を行う。

平板型セルの境界辺を完全固定し, 瞬間的に $80 \mathrm{MPa}$ の 等分布荷重を作用させ，そのまま $4000 \mathrm{sec}$ 保持する．た だし，板状デバイスの対称性を考慮し，解析では図15(a)に示すような $1 / 4$ 対称モデルとする。また，積層シ エル要素にはAbaqus2017に搭載された連続体ソリッドシ エル要素を使用する．この連続体ソリッドシェル要素は 通常のソリッド要素と同じように，要素を積み重䄈るこ とができるため, 本解析では各層の厚さを 1 要素とする 連続体ソリッドシェル要素からなる積層代理モデルを設 定した．連続体ソリッドシェル要素の仕様については付 録を参照されたい，比較のために，図-15(b)に示すよう

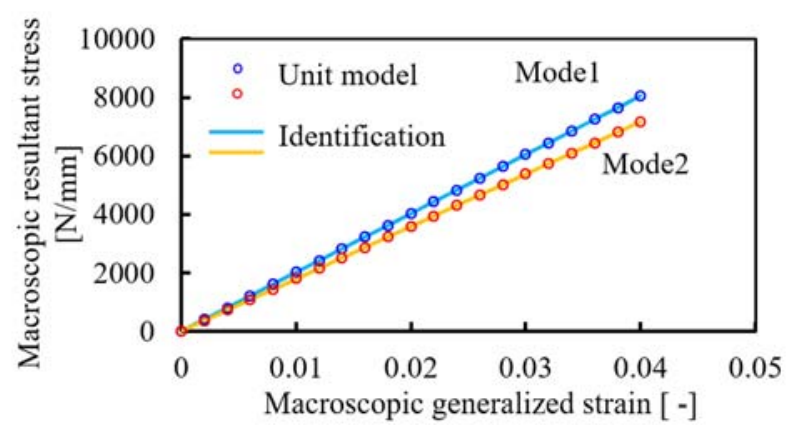

(a) Tension

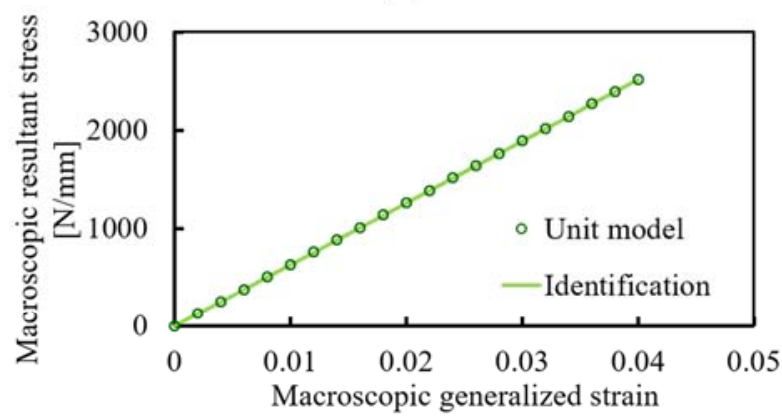

(b)In-plane shear

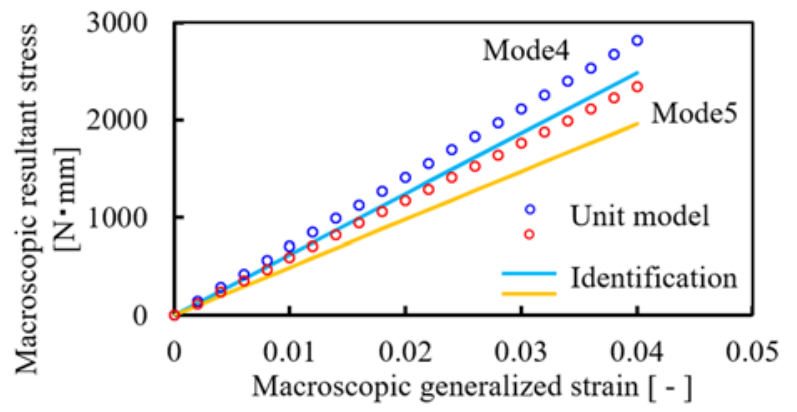

(c) Bending

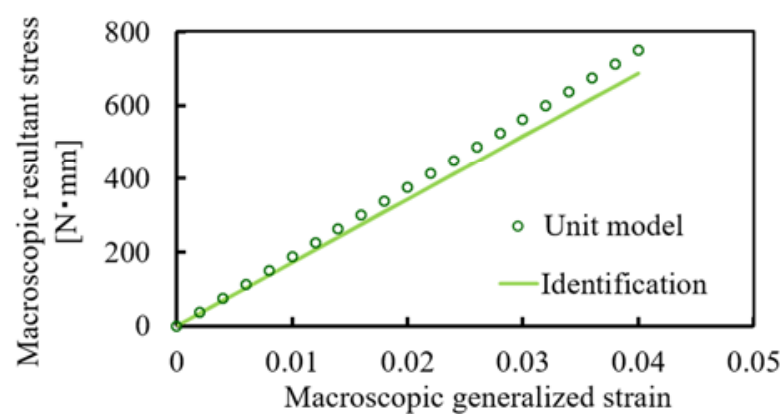

(d) Torsion

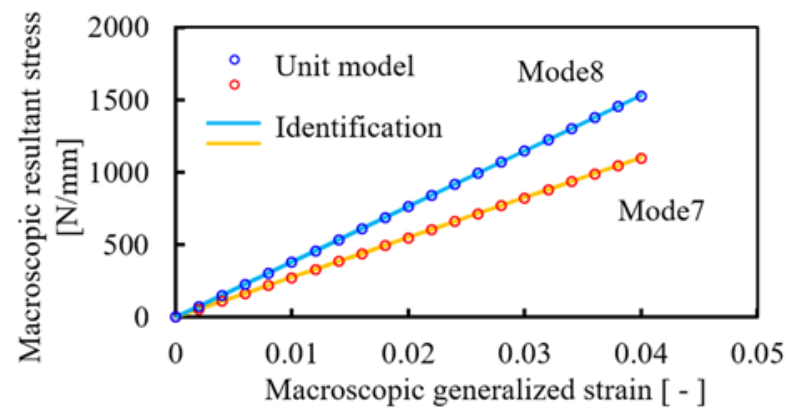

(e) Out-of-plane shear

図-14 同定結果（非弾性特性を除いた同定） 


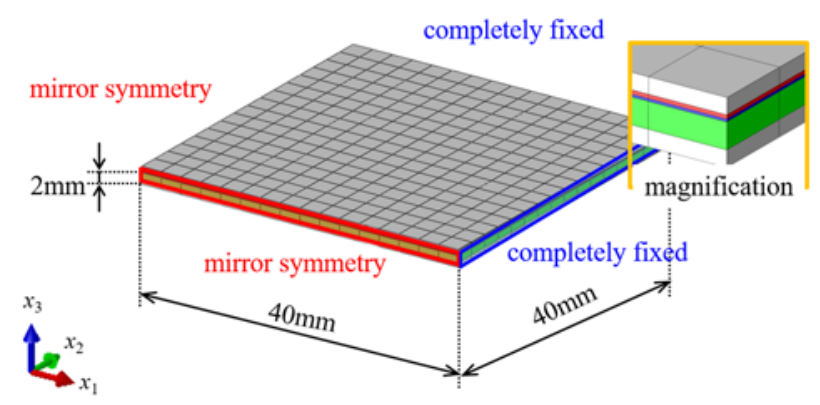

(a) Continuum solid-shell elements

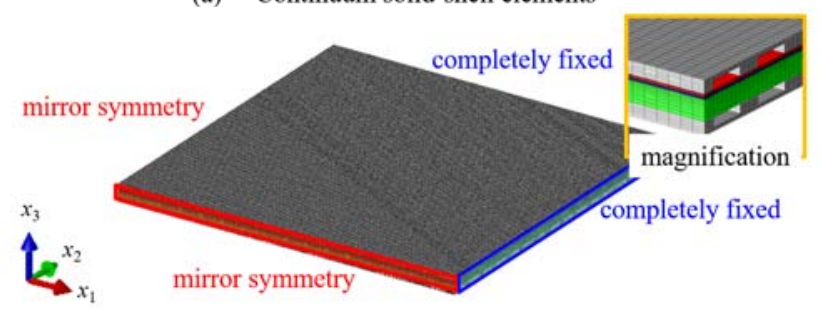

(b) Solid elements

図-15 マクロ解析のモデルと境界条件

表-3 節点数，要素数および解析時間

\begin{tabular}{c|c|c}
\hline & Solid-Shell & Solid \\
\hline Nodes & 1734 & 404594 \\
\hline Elements & 1280 & 358400 \\
\hline $\begin{array}{c}\text { Analysis time } \\
{[\mathrm{sec}]}\end{array}$ & 64 & $41260(6 \mathrm{CPU})$ \\
\hline
\end{tabular}

な面内周期性を有する面内ユニット構造をそのまま面内 に並べて 3 次元ソリッド要素で作成した平板型セルにつ いても同様の解析を行う。

それぞれの節点数，要素数および解析に要した時間を 表-3 に示す。ソリッド要素を用いた解析では，6CPU の 並列計算で約 11 時間かかったが，本手法では並列計算 せずに 64 秒と, 解析時間を大幅に短縮できることが分 かる. 本手法を用いる場合, 平板型セルの構造や材料が 異なるごとに材料定数の同定を行う必要があるが，実機 相当の平板型セルを直接モデル化し解析を行うと膨大な 計算コストが必要になるのに対し，提案する本手法の積 層代理モデルを用いることで，このコストを削減するこ とが可能になる. また，数 $\mathrm{kW}$ 級のセルスタックを解析 する場合, 平板型セルを数十枚重ねる必要があるため, ソリッド要素を用いることは要素数や解析時間の観点か ら現実的でなく，本手法の有用性が主張できる.

図-16 に最終時刻の変形形状を示す。コンターは $x_{3}$ 方 向の変位分布を表す．図-17 には，上面の中心部分にお ける変位履歴曲線を示寸. 最終時刻の中心部分の $x_{3}$ 方向 の変位は，ソリッド要素を使用した解析では-7.98mm あ ったのに対し，本提案手法を用いた連続体ソリッドシェ ル要素による解析結果は-7.79mm であり比較的良好な結

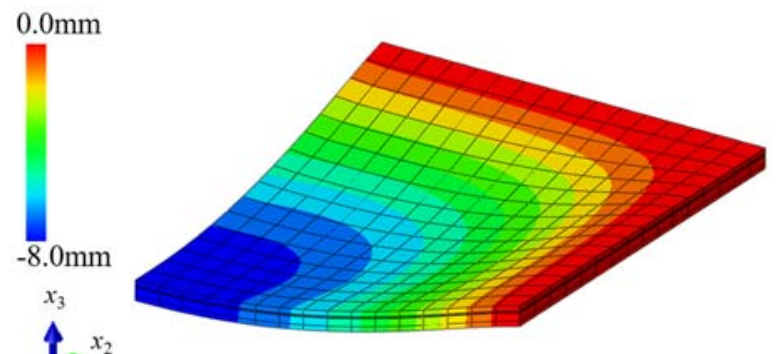

(a) Continuum solid-shell elements

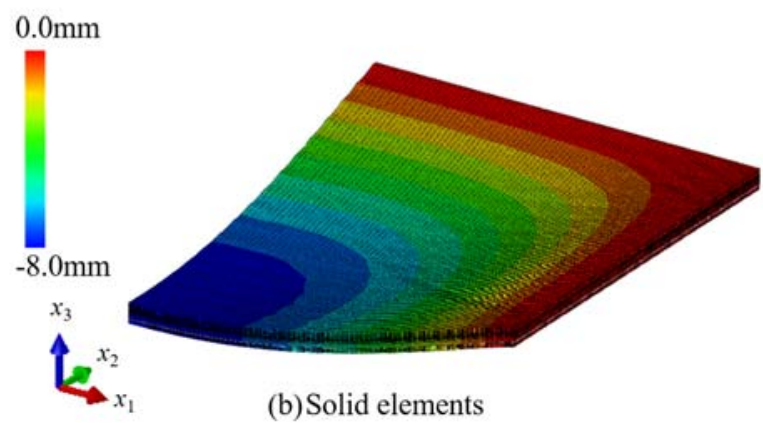

図-16 マクロ解析の変形形状 $\left(x_{3}\right.$ 方向変位分布)

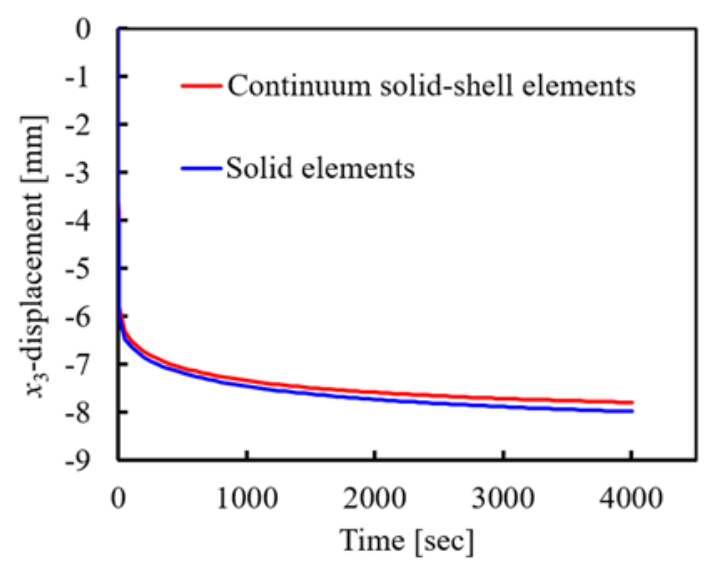

図-17 $x_{3}$ 方向変位履歴曲線

果が得られている.

最後に, 図-18 に上部のインターコネクトに発生する 面外方向のせん断応力を示す．これより，インターコネ クトに異方性が現れていることが確認できる. 通常の積 層シェル要素では，面外方向の応力を評価できないが, 連続体ソリッドシェル要素を用いることによって，厚さ 方向に関する評価が可能となる.

以上の結果から，SOFC の平板型セルような非弾性特 性を有する板状デバイスにおいて，本研究で提案した積 層代理モデルを用いることで精度よく評価することがで きることが確認された．また，連続体ソリッドシェル要 素を用いることで厚さ方向の挙動についても検討可能な ことが例示された. 


\section{6. 結言}

本研究では SOFC の平板型セルのような板状デバイス を対象として，その面内ユニット構造に対する数值平板 特性試験により非線形マクロ力学挙動を特徵付け, この 挙動と等価な挙動を発現しうる代理モデルにより，マク 口解析を行うことが可能なマルチスケール解析手法を提 案した. マクロ構造には厚板理論を採用し, ミクロ構造 には，平板型セルの面内ユニット構造を 3 次元固体とし てモデル化し，等価な非弾性均質体としての非線形力学 挙動を算出可能な変位場と, その境界条件を付与した.

数值解析に際しては，平板型セルを対象に汎用 FEM ソフトウェアの Abaqus/Standardによる面内ユニット構造 の数值平板特性試験の解析を行い，これと等価な挙動を 発現しうる積層構造の代理モデルを設定したうえで, 各 層の均質体としての材料定数を同定した. 得られた材料 定数を用いた連続体ソリッドシェル要素によるマクロ解 析を行い, 結果の精度を検証した.

本研究で提案した平板型セルの非弾性のミクロ-マク 口連成解析手法を用いることにより，すべてを固体有限 要素でモデル化した解析と比較して解析時間を大幅に短 縮し, ミクロな変形挙動を考慮したセル全体の非線形力 学挙動の評価が可能になった。

本研究では，インターコネクトの周期構造に着目した。 しかしながら，平板型セルの構造は設計によって全く異 なる形状であり，インターコネクトだけではなく各構成 部材が面内に周期構造を有する場合もしばしばある。こ のような場合においても，本手法の数值平板特性試験と 均質な板を積み重ねた積層代理モデルを導入することに より, 平板型セルのマクロ解析が可能となる. また, Abaqusの連続体ソリッドシェル要素を用いることで積層 構造のセルをモデル化でき，何層にも重ねたセルスタッ ク形状にすることも可能になる. このセルスタックの解 析は今後の課題である. さらに将来的には，還元膨張や 熱膨張を考慮した解析システムと組み合わせることによ り, 平板型セルの非定常電気化学-力学連成のミクロ-マ クロ解析手法一発展させる.

謝辞 : 本論文は，新エネルギー・産業技術総合開発機構 (NEDO) の委託業務の結果得られたものである.

\section{付録 連続体ソリッドシェル要素 22)}

Abaqus2017 で新たに搭載された連続体ソリッドシェル 要素は Vu-Quoc らによって提案された要素 23)を基に作ら れた 1 次要素である。体積ロッキングを軽減するために 曲げ変形と想定されるひずみを改良した要素であり, 変

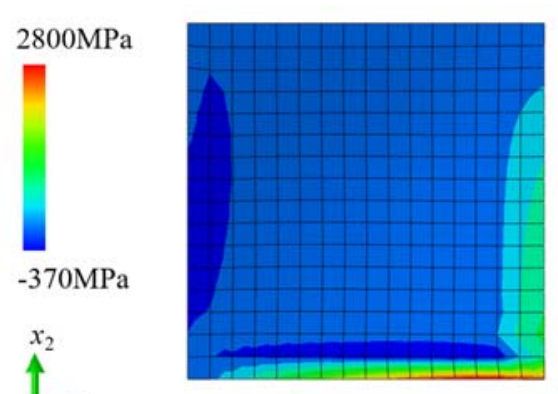

(a) Shear stress : $\tau_{x_{1}, x_{3}}$

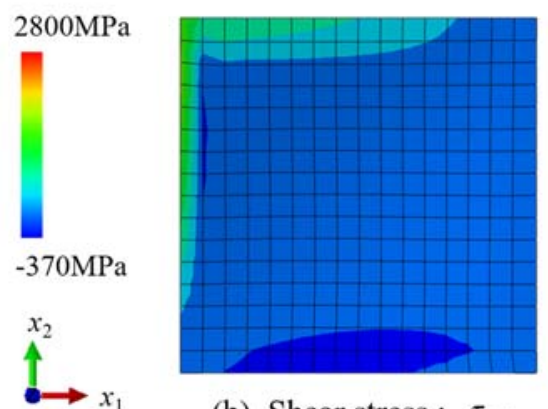

(b) Shear stress : $\tau_{x_{2} x_{3}}$

図-18上側のインターコネクトに発生する 面外方向の応力分布

位の自由度のみを持つ. 3 次元構成則を使用し, 通常の ソリッド要素よりアスペクト比の大きな曲げに対して良 好な応答を示す．また，想定されるひずみは面内応答と は異なる厚さ方向の応答より求められる. ただし, 複合 材を含む薄い構造に適した要素であり, 厚さをもつ要素 については結果が保証されないため注意が必要である.

\section{参考文献}

1) A. Atkinson : Chemically-induced stresses in gadoliniumdoped ceria solid oxide fuel cell electrolytes, Solid State Ionics, Vol.95, pp.249-258, 1997

2) A. Atkinson and T. M. G. M. Ramos : Chemically-induced stresses in ceramic oxygen ion-conducting membranes, Solid State Ionics, Vol.129, pp. 259-268, 2000.

3) H. Yakabe, M. Hishinuma and I. Yasuda : Static and transient model analysis on expansion behavior of $\mathrm{LaCrO}_{3}$ under an oxygen potential gradient, Journal of The Electrochemical Society, Vo.147-11, pp. 4071-4077, 2000.

4) C. K. Lin, T. T. Chen, Y. P. Chyou and L. K. Chiang : Thermal stress analysis of planar SOFC stack, Journal of Power Sources, Vol.164-1, pp. 238-251, 2007.

5) C. K. Lin, L. H. Huang, L. K. Chiang and Y. P. Chyou : Thermal stress analysis of planar solid oxide fuel cell stacks : Effects of sealing design, Journal of Power Sources, Vol.192-2, pp. 515-524, 2009.

6) A. Nakajo, Z. Wuillemin, J. V. Herle, and D. Favrat : Simulation of thermal stresses in anode-supported solid oxide fuel cell stacks. Part I: Probability of failure of the cells, Journal of Power Sources, Vol.193-1, pp. 203-215, 2009.

7) A. Nakajo, Z. Wuillemin, J. V. Herle, and D. Favrat : Simulation of thermal stresses in anode-supported solid oxide 
fuel cell stacks. Part II: Loss of gas-tightness, electrical contact and thermal buckling, Journal of Power Sources, Vol.193-1, pp. 216-226, 2009.

8) K. Terada, T. Kawada, K. Sato, F. Iguchi, K. Yashiro, K. Amezawa, M. Kubo, H. Yugami, T. Hashida, J. Mizusaki, H. Watanabe, T. Sasagawa and H. Aoyagi : Multiscale Simulation of Electro-Chemo-Mechanical Coupling Behavior of PEN Structure under SOFC Operation, ECS Transactions, Vol.35-1, pp. 923-933, 2011.

9) M. Muramatsu, K. Terada, T. Kawada, K. Yashiro, K. Takahashi and S. Takase : Characterization of time-varying macroscopic electro-chemo-mechanical behavior of SOFC subjected to Ni-sintering in cermet micro-structures, Computational Mechanics, Vol.56-4, pp. 653-676, 2015.

10) M. Muramatsu, K. Yashiro, T. Kawada and K. Terada : Numerical simulations of non-stationary distributions of electrochemical potentials in SOFC, Engineering Computations, Vol.34-6, pp. 1956-1988, 2017.

11）佐藤維美，村松眞由，寺田賢二郎，渡辺智，八代圭 司，川田達也，横川晴美 : 汎用 FEMソフトウェアを プラットフォームとする固体酸化物形燃料電池の非 定常電気化学 - 力学連成解析システムの開発, 計算 工学会論文集, Vol.2017, p. 20170004, 2017.

12) N. Buannic, P. Cartraud and T. Quesnel : Homogenization of corrugated core sandwich panels, Composite Structures, Vol.59-3, pp. 299-312, 2003.

13) A. Cecchi and K. Sab : A homogenized Reissner-Mindlin model for orthotropic periodic plates: Application to brickwork panels, Int. J. of Solids and Structures, Vol.44, pp. 6055-6079, 2007.

14) M. G. D. Geers, E. W. C. Coenen1 and V. G. Kouznetsova : Multi-scale computational homogenization of structured thin sheets, Modeling and Simulation in Materials Science and engineering, Vol.15, S393-S404, 2007.

15) B. Abbès and Y.Q. Guo, : Analytic homogenization for tor- sion of orthotropic sandwich plates: Application to corrugated cardboard, Composite Structures, Vol. 92-3, pp. 699706, 2010.

16) C. Y. Lee and W. Yu : Homogenization and dimensional reduction of composite plates with in-plane heterogeneity, Int. J. of Solids and Structures, Vol. 48-10, pp. 1474-1484, 2011.

17) K. Terada, N. Hirayama, K. Yamamoto, M. Muramatsu, S. Matsubara and S. Nishi : Numerical plate testing for linear two-scale analyses of composite plates with in - plane periodicity, Int. J. for Numerical Methods in Engineering, Vol.105-2, pp. 111-137, 2016.

18) S. Matsubara, S. Nishi and K. Terada : On the treatments of heterogeneities and periodic boundary conditions for isogeometric homogenization analysis, Int. J. for Numerical Methods in Engineering, Vol.109-11, pp. 1523-1548, 2017.

19) 佐藤浩, 小野功, 小林重信 : 遺伝的アルゴリズムに おける世代交代モデルの提案と評価, 人工知能学会 誌, Vol.12, No.5, pp. 734-744, 1997.

20) 秋本洋平, 羽佐田理恵, 佐久間淳, 小野功, 小林重 信 : 多親を用いた実数值 GA のための世代交代モデ ル Just Generation Gap(JGG)の提案と評価, 第 19 回自 立分散システムシンポジウム資料, pp. 341-346, 2007.

21) 秋本洋平, 永田裕一, 佐久間淳, 小野功, 小林重 信 : 適応的実数值交叉 AREX の提案と評価, 人工知 能学会論文誌, Vol.24, No.6, A, 2009.

22) Abaqus2017 Users Manual, 2017.

23) L. Vu-Quoc, X. G. Tan : Optimal solid shells for non-linear analyses of multilayer composites. I. Statics, Computer Methods in Applied Mechanics and Engineering, Vol.192, pp. 975-1016, 2003.

(2017.6. 23 受付)

\section{NUMERICAL PLATE TESTING FOR NON-LINEAR MULTI-SCALE ANALYSIS OF PLATE-SHAPED DEVICE}

\section{Masami SATO, Mayu MURAMATSU, Seishiro MATSUBARA, Shinnosuke NISHI, Kenjiro TERADA, Keiji YASHIRO and Tatsuya KAWADA}

We propose a new method of multi-scale analysis for plate-like devices such as a flat plate cell of solid oxide fuel cell (SOFC), which is classified into a composite plate composed of in-plane periodic structures. To characterize the macroscopic nonlinear mechanical behavior of the in-plane periodic structure, the method of numerical plate testing is employed. Since the obtained relationships between macroscopic generalized strains and stress cannot be represented by an equivalent homogeneous plate with a single material, we introduce a surrogate model composed of homogeneous layers that is expected to exhibit the same macroscopic responses. After the material parameters of these layers are identified, the macroscopic analysis becomes possible by use of a laminated structure with continuum solid shell elements available in a general-purpose finite element program. Representative numerical examples are presented to demonstrate the capability of the proposed multi-scale analysis method. 